\title{
Assessment of Immunostimulating effect of Carica papa- ya-based Immunostimulatory Complexes Against Streptococcus pneumoniae Infections
}

\author{
Tamunotonye Abel Briggs ${ }^{1,2}$, Angus Nnamdi Oli ${ }^{1, *}$, Ebere Innocent Okoye ${ }^{3}$, AyokunnumiFunke Obajuluwa ${ }^{4}$, ChineloKene Ezejiegu $^{1}$, \\ Chijioke Maxwell Ofomata ${ }^{5}$, Gordon C. Ibeanu ${ }^{6}$ \\ 'Department of Pharmaceutical Microbiology and Biotechnology, Faculty of Pharmaceutical Sciences, Nnamdi Azikiwe University Awka, Anambra, NIGERIA. \\ 2Department of Science Laboratory Technology, School of Sciences, Akanulbiam Federal Polytechnic Unwana, Afikpo, Ebonyi, NIGERIA. \\ 3Department of Pharmaceutics and Pharmaceutical Technology, Faculty of Pharmaceutical Sciences, Nnamdi Azikiwe University Awka, Anambra, NIGERIA. \\ ${ }^{4}$ Department of Pharmaceutical Microbiology and Biotechnology, Faculty of Pharmaceutical Sciences, Kaduna State University, Kaduna, NIGERIA. \\ SDepartment of Clinical Pharmacy and Pharmacy Management, Faculty of Pharmaceutical Science, Nnamdi Azikiwe University Awka, Anambra, NIGERIA. \\ ${ }^{6}$ Department of Pharmaceutical Science, North Carolina Central University, Durham, NC, USA.
}

\begin{abstract}
Objectives: Streptococcus pneumoniae infection is a bacterial infection responsible for one-fifth of child mortality in Africa. The aim of this study was to formulate and evaluate Carica papaya-based Immunostimulatory complexes against Streptococcus pneumoniae infections. Methods: Leaves of the plant were harvested, air-dried, pulverized and the saponin content extracted using distilled water and but anole in a Soxhlet's apparatus. The formulation of Immunostimulatory complexes was prepared using the ethanol injection method. Acute toxicity test and Immunological assays, namely: neutrophil adhesion, carbon clearance, hem agglutinating antibody titer were conducted using healthy laboratory mice. The results were compared to standard drug (levamisole). Results: The aqueous extract and butanol fraction yielded $7.45 \%$ and $0.38 \%$ saponin. At $5000 \mathrm{mg} /$ $\mathrm{kg}$ body weight of administered immunostimulatory complexes, no death or behavioral changes were recorded. Neutrophil adhesion showed no significant increase $(20.82 \pm 4.34)$ as against the levamisole $(20.74 \pm 3.31)$. The increased phagocytic index $(0.089 \pm 0.017)$ showed better stimulation of reticuloendothelial system when compared to both controls (distilled water $=0.032 \pm 0.001$; levamisole $=0.071 \pm 0.001$ ). The lower Hemagglutination
\end{abstract}

antibody titre value indicates the potency of the formulated ISCOM to elicit an immune response. The ISCOM dose $(250 \mathrm{mg} / \mathrm{kg}$ body weight)

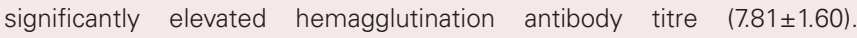
Conclusion: It can be inferred from this study that Carica papaya leaves has immunomodulatory capacity and has significant saponin yield which could potentially serve as a component of Immunostimulatory complexes formulation. Carica papaya-based Immunostimulatory complexes exhibit improved immunogenicity against Streptococcus pneumoniae infections. Key words: Immunity, Adjuvant, ISCOMs, Streptococcus pneumoniae, Carica papaya, Saponin, ISCOMATRIX.

\section{Correspondence}

Angus Nnamdi Oli

Department of Pharmaceutical Microbiology and Biotechnology, Faculty of Pharmaceutical Sciences, Nnamdi Azikiwe University Awka, Anambra, NIGERIA. Phone no: +234-8056306927

Email: a.n.oli@live.com

DOI: 10.5330/ijpi.2020.3.68

\section{INTRODUCTION}

Papaya (Carica papaya) is a large succulent herbaceous plant that has medicinal and nutritional properties. It is considered a nutraceutical fruit because of its several medicinal qualities such as wound healing, antifungal and anti-bacterial activities. ${ }^{1}$ Phytochemical analysis reveals the presence of papain (enzyme), cardiac glycosides, lycopene, carotenoids, alkaloids, flavonoids and vitamins. ${ }^{2}$ The presence of saponin in the leaves confers cytotoxic effects on the plant. ${ }^{3}$ Papaya leaf green tea is taken to aid digestion and treat ailments like chronic indigestion, overweight and obesity and cardiovascular associated health problems. ${ }^{4}$

Streptococcus pneumoniae or pneumococcus, a Gram-positive cocci bacterium, isalpha-haemolytic under aerobic conditions or betahaemolytic under anaerobic conditions. It is a facultative anaerobic member of the genus Streptococcus. Streptococcus pneumoniae is the most common cause of pneumonia and invasive and non-invasive mucosal diseases. ${ }^{5}$ Streptococcus pneumoniae infections are responsible for one-fifth of child mortality in Africa. ${ }^{6,7}$ The bacterium colonizes the nasopharynx and is responsible for bacteraemia, pneumonia, meningitis, otitis media. ${ }^{8,9}$ Although pneumococcal diseases can occur in all ages, they are prone to occur in elderly, infants, cancer patients with compromised immune system. ${ }^{9-11}$

The immune system is made up of a complex network of cells with the ability to protect the body from the harmful effect of pathogens and toxic substances. ${ }^{12,13}$ This pathogens or toxic substances include toxins, bacteria, fungi, parasites, prions, viruses. The immune cells are located in various parts of the body like the mucosa of the internal organs, eyes, skin, bone marrow and blood. They are specialised aggregate cells that ward off and fight pathogens. Adaptive and Innate immunity are components of the immune system that mobilizes broad collection of responses against pathogens and have the ability to distinguish body tissues from foreign agents. Phagocytic mechanism is employed by the immune system to combat pathogens by engulfment and digestion. Immune cells such as neutrophils, macrophages, mast cells and monocytes are responsible for phagocytosis. Immune boosters or immune stimulants are often used to improve resistance against infections in the body and can respond via innate and adaptive immune responses. ${ }^{6}$ Immune stimulants may be biological or synthetic in nature. ${ }^{12,13}$ In immunocompromised 
individuals, they tend to be curative as therapeutic agents while as prophylactic and boosters in healthy subjects. ${ }^{14}$

The immunostimulating effect of vaccines as a means of combating infectious diseases have drastically reduced the rate of morbidity and mortality globally. Vaccines combat the effect of pathogens by stimulating protective long lasting immune responses. ${ }^{15}$ The need for improvement of the immunogenicity and efficacy of vaccine leads to the use of adjuvants. Adjuvants are immune boosters that respond to the effect of a particular antigen. Immunostimulating complexes (ISCOMs) are adjuvants that are made up of Saponin, Cholesterol and Phospholipid. ISCOMs are "adjuvant with multiple adjuvant properties" that are "open cage-like complexes typically with a diameter of about $40 \mathrm{~nm} .{ }^{16}$ and have been demonstrated to promote antibody responses and induce Thelper cell as well as cytotoxic T lymphocyte responses. ${ }^{16,17}$ They can function both as vaccine adjuvants and vaccine delivery system. ISCOMs are unique in their ability to provoke a wide range of protective B-cell and T-cell responses to protein antigens following either oral or parenteral vaccination. "The adjuvant properties of ISCOM-matrix fulfill the demands of a modern adjuvant: a formulation with dose-sparing capacity, improved quality of immune responses and an acceptable safety profile" ${ }^{17}$

The immense benefits of currently available pneumococcal vaccines, notwithstanding, the discovery and implementation of additional vaccine platforms is of uttermost importance due to the inherent shortcomings of those available pneumococcal vaccines. To improve on this limitation, Carica papaya-based ISCOM-matrix with its unique ability to provoke long-lasting protective immune responses was formulated and evaluated for improved immunogenicity against Streptococcus pneumoniae infections.

\section{MATERIALS AND METHODS}

\section{Plant material}

The Carica papaya leaves were collected from Afikpo, Ebonyi State, Nigeria, in August 2016 and identified at the Department of Pharmacognosy, Faculty of Pharmaceutical Sciences; Aguluof Nnamdi Azikiwe University in Anambra State. The leaves were air dried in a cool dry place away from sun and pulverized to powder. Two (2) $\mathrm{kg}$ of the grounded C. papaya leaves was soaked in ethanol at a ratio of 1:5 for 2 days and then filtered through a muslin cloth. The residue was discarded while the filtrate was concentrated through evaporation technique under reduced pressure at $45^{\circ} \mathrm{C}$ using a rotary evaporator.

\section{Extraction and fractionation to obtain saponin}

Extraction and fractionation method as described by Okigbo et al. ${ }^{3}$ was used to extract the saponin from the C. papaya leaves. The total yield of C. papaya extract was calculated using the formula:

Extract yield $(\%)=\frac{(\text { ExtractedMaterial }) 100}{\text { DriedMaterial }}$

Eqt. 1

\section{Experimental animals and test organisms}

The weight range of the mice (Mus musculus) used for the study was 20-30g (male and female gender) and aged 5-6 weeks old. They were sourced from the Department of Zoology, University of Nigeria Nsukka and fed for a week under pathogen free condition before being used for experiments. The animals were handled according to established guidelines. ${ }^{18-20}$ while the ethical approval was obtained from the Ethics Committee of the Faculty of Pharmaceutical Sciences, Nnamdi Azikiwe University Awka Nigeria. Used animals were euthanized using isoflurane and buried after death.
Clinical isolates of Streptococcus pneumoniae were obtained from stock samples in the Laboratory of the Department of Pharmaceutical Microbiology and Biotechnology, Faculty of Pharmaceutical Sciences, Nnamdi Azikiwe University Awka, Anambra State, Nigeria. The specimen was re-activated by incubating in nutrient broth at $37^{\circ} \mathrm{C}$ for 24 $\mathrm{hr}$ and sub-cultured onto sterile Blood Agar. The plates were incubated at $37^{\circ} \mathrm{C}$ with $5-10 \% \mathrm{CO}_{2}$ for $24-48 \mathrm{hr}$ and observed for growth after which Gram staining and biochemical tests were carried out for confirmation.

\section{Preparation of ISCOMATRIX}

The ISCOMATRIX adjuvant was formulated using Ethanol injection method (Direct and Reverse) as reported previously. ${ }^{21,22}$

\section{Acute toxicity study}

Hybrid methodsof Lorke's ${ }^{23}$ and Sahgal et al. ${ }^{24}$ were used. The method involves two phases consisting of a total of seventeen animals. The first phase consisted of nine animals divided into three groups of three animals each. Each group of animal were administered different doses of 10,100 and $1000 \mathrm{mg} / \mathrm{kg}$ of the test substance. The animals were afterwards observed for $24 \mathrm{hr}$ to check behavioural characteristics and death. The second phase involved the use of eight mice which were distributed into four groups of two animals each. The animals were administered 2000, 3000,4000 and $5000 \mathrm{mg} / \mathrm{kg}$ doses of test substance and then observed for $24 \mathrm{hr}$ for behavioural changes and mortality.

\section{Immunological evaluation}

Neutrophil adhesion test: Mallurwar et al..$^{25}$ method was used with slight modifications. The mice were grouped into six of five animals per group. Group 1 mice were administered distilled water only $(10 \mathrm{~mL})$, Group 2 were administered $100 \mathrm{mg} / \mathrm{kg}$ of levamisole which is the positive control, Group 3 were administered $250 \mathrm{mg} / \mathrm{kg}$ of test substance - the formulated ISCOM, Group 4 were administered $0.1 \mathrm{ml}$ of Streptococcus pneumoniae suspension containing $0.5 \times 10^{9} /$ cells only which serve as negative control, Group 5 were administered $0.1 \mathrm{ml}$ of Streptococcus pneumoniae suspension containing $0.5 \times 10 \%$ cells then followed by 250 $\mathrm{mg} / \mathrm{kg}$ of ISCOM, Group 6 were administered $250 \mathrm{mg} / \mathrm{kg}$ then followed with $0.1 \mathrm{ml}$ of Streptococcus pneumoniae suspension containing $0.5 \times 10^{9} /$ cells. Blood samples were collected from all groups on the $14^{\text {th }}$ day of treatment by puncturing the retro-orbital plexus under mild isoflurane anaesthesia. Blood was collected in pre-treated disodium EDTA vials and analysed for total leucocyte count. The blood sample drawn was diluted with Turk's fluid in WBC pipette, in which red cells were lysed without affecting the leucocyte population. Leucocytes were counted using improved Neubauer's counting chamber.

In differential leucocyte count (DLC), blood smear was prepared on a clean glass slide and stained with Leishman's and field 1 stains. The differential populations of leucocytes were differentiated and identified based on the cell size, presence of granules, colour and shape of nucleus under the microscope using immersion oil. After initial counts, blood samples were inoculated with $80 \mathrm{mg} / \mathrm{ml}$ of nylon fibre for $15 \mathrm{~min}$ at $37^{\circ} \mathrm{C}$. The incubated blood samples were analysed for Total Leucocyte Count (TLC) and DLC. The product of TLC and \% neutrophil gives neutrophil index (NI) of blood sample. Percentage of neutrophil adhesion was calculated as

Neutrophil Adhesion $(\%)=\frac{(\mathrm{NIu}-\mathrm{Nit}) 100}{\mathrm{NIu}} \quad$ Eqt. 2

Where NIu is neutrophil index of untreated blood samples, Nit is neutrophil index of treated blood samples.

Carbon clearance assay: Carbon Clearance Assay was done according to the method described by Cheng et al. ${ }^{26}$ Mice were divided into six 
groups of five animals per group. Group 1 mice were administered distilled water only $(10 \mathrm{ml})$, Group 2 were administered $(100 \mathrm{mg} / \mathrm{kg})$ of levamisole which is the positive control, Group 3 were administered $(250 \mathrm{mg} / \mathrm{kg})$ of test substance ISCOM, group 4 were administered $0.1 \mathrm{ml}$ of Streptococcus pneumoniae suspension containing $0.5 \times 10 \%$ cells only which serve as negative control, Group 5 were administered $0.1 \mathrm{ml}$ of Streptococcus pneumoniae suspension containing $0.5 \times 10^{9} /$ cells then followed by $250 \mathrm{mg} / \mathrm{kg}$ of ISCOM, Group 6 were administered $250 \mathrm{mg} /$ $\mathrm{kg}$ then followed with $0.1 \mathrm{ml}$ of Streptococcus pneumoniae suspension containing $0.5 \times 10^{9} /$ cells. On the $7^{\text {th }}$ day of treatment, mice of all groups received an intravenous injection of $0.5 \mathrm{ml}$ Indian ink solution (prewarmed at $37^{\circ} \mathrm{C}$ ). Blood samples were then collected from retro-orbital bleeding using glass capillaries at an interval of 3 and 10 min after injection of ink dispersion. $50 \mu \mathrm{l}$ blood samples were added to $4 \mathrm{ml}$ of 0.1 $\%$ sodium carbonate solution to lyse the erythrocytes and absorbance of these samples was measured at $675 \mathrm{~nm}$ using spectrophotometer, after 10 min. Rates of carbon clearance $(\mathrm{K})$ and phagocytic index were calculated using the formula:

Rate of carbon clearance $(K)=\frac{\log \mathrm{OD}_{3}-\log \mathrm{OD}_{10}}{\mathrm{~T}_{2}-\mathrm{T}_{1}} \quad$ Eqt. 1

$\mathrm{OD}_{3}$ is the absorbance of blood at $3 \mathrm{~min}, \mathrm{OD}_{10}$ is the absorbance of blood at $10 \mathrm{~min}, \mathrm{~T}_{2}$ is the last time point of blood collection and $\mathrm{T}_{1}$ is the first time point of blood collection

Rate of carbon clearance and phagocytic index of treated group mice was compared with the control group animals.

Hemagglutinating antibody (HA) titre: Hemagglutinating antibody titre was determined as reported by earlier researchers. ${ }^{27,28}$ The animals were challenged by injecting $0.1 \mathrm{ml}$ of Streptococcus pneumoniae suspension containing $0.5 \times 10^{9} /$ cells intra-peritoneal on day 0 . The test ISCOM was administered separately to all mice continuously for 7 days. Blood samples were collected in micro-centrifuge tubes from individual mice by retro-orbital puncture on $7^{\text {th }}$ day. The blood samples were centrifuge at $2500 \mathrm{rpm}$ for $10 \mathrm{~min}$ to obtain the serum. Antibody levels were determined by the hemagglution technique. Equal volumes of individual serum samples of each group were pooled and two fold serial dilutions of samples made in $25 \mu \mathrm{l}$ volume of normal saline in micro-titre plates with $25 \mu \mathrm{l}$ of $1 \%$ suspension of Streptococcus pneumoniae in saline. After mixing, the plates were then incubated at $37^{\circ} \mathrm{C}$ for $1 \mathrm{hr}$ and examined

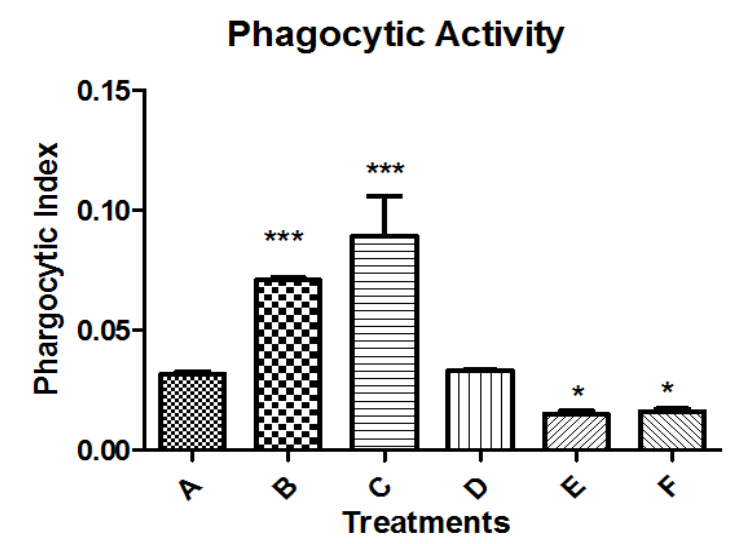

Figure 1: Index of phagocytic activity in the carbon clearance. ( $\mathbf{A}=$ Distilled Water $(10 \mathrm{ml} / \mathrm{kg}) ; \mathbf{B}=$ Levamisole $(100 \mathrm{mg} / \mathrm{kg}) ; \mathbf{C}=$ ISCOM only $(250 \mathrm{mg} / \mathrm{kg}) ; \mathbf{D}=$ Organism only $(0.1 \mathrm{ml} / \mathrm{kg}) ; \mathbf{E}=$ Organism+ISCOM $(0.1 \mathrm{ml} / \mathrm{kg}+250 \mathrm{mg} / \mathrm{kg})$ while $\mathbf{F}=$ ISCOM+Organism (250mgmg/kg+0.1 ml/kg).

Data are presented as means $\pm \operatorname{SEM}(n=3) .{ }^{*} p<0.05 ;{ }^{* * *} p<0.01$ compared to organism only for hem agglutination. The reciprocal of the highest dilution of the test serum showing agglutination was taken as the antibody titre.

\section{Statistical analysis}

Statistical analysis was performed using Graph pad Prism Software Version 5.0. All the results were expressed as Mean \pm Standard Error Mean (SEM). Data were analysed using one-way Analysis of Variance (ANOVA) followed by Dennett Multiple comparison test. $P$-values < 0.05 were considered significant.

\section{RESULTS}

\section{Percentage yields of Carica papaya extract}

Table 1 shows percentage yields/composition of saponin crude aqueous extract and butanol fraction of C. papaya. Plants were extracted with aqueous or butanol and the composition of saponins in the extracts calculated as a percentage of the dried leaves.

\section{Iscomatrix formulation}

The ISCOM formulated using the rapid injection method had clear colloidal suspension with a foamy top layer in appearance and lightly yellow in colour, while ISCOM formulated using the reverse rapid injection method had a cloudy colloidal suspension with foamy top layer a yellow colouration.

\section{Acute toxicity study}

This was done to evaluate the toxicity and behavioural effects of the C. papaya-based ISCOMATRIX on animal models. The ISCOM administered at several doses of $10,100,1000$, to $5000 \mathrm{mg} / \mathrm{kg}$ body weight in two phases of toxicity study showed no lethality after 7 days of treatment. This suggests that the $\mathrm{LD}_{50}$ of the ISCOM is above $5000 \mathrm{mg} /$ $\mathrm{kg}$ body (Table 2). In addition, no changes in behaviour were observed in the animals at the highest dose of $500 \mathrm{mg} / \mathrm{Kg}$ body weight tested after 24 hr observation.

Table 1: Percentage yields of crude aqueous extract and butanol fraction.

\begin{tabular}{cc}
\hline Solvents & Percentage yield (\%) \\
\hline Aqueous & 7.45 \\
Butanol & 0.38 \\
\hline
\end{tabular}

\section{Hemagglutination Titre}

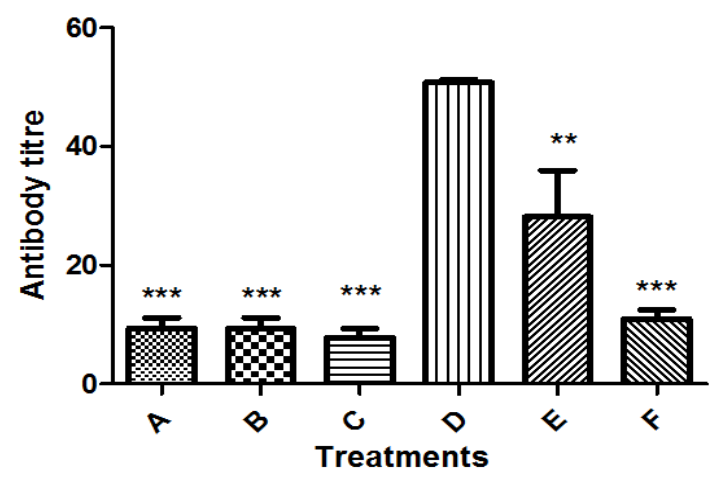

Figure 2: Hemagglutinating Antibody Titre. (A=Distilled Water $(10 \mathrm{ml} / \mathrm{kg}) ; \mathbf{B}=$ Levamisole $(100 \mathrm{mg} / \mathrm{kg}) ; \mathbf{C}=$ ISCOM only $(250 \mathrm{mg} / \mathrm{kg}) ; \mathbf{D}=$ Organism only $(0.1 \mathrm{ml} /$ $\mathrm{kg}) ; \mathbf{E}=$ Organism+ISCOM $(0.1 \mathrm{ml} / \mathrm{kg}+250 \mathrm{mg} / \mathrm{kg})$ while $\mathbf{F}=$ ISCOM+Organism $(250 \mathrm{mgmg} / \mathrm{kg}+0.1 \mathrm{ml} / \mathrm{kg})$ ). 
Table 2: $\mathrm{LD}_{50}$ of the formulated ISCOM.

\begin{tabular}{cccccc}
\hline Phases & TreatmentGroups & $\begin{array}{c}\text { Number of } \\
\text { Animals }\end{array}$ & $\begin{array}{c}\text { Doses administered } \\
(\mathrm{mg} / \mathrm{Kg})\end{array}$ & $\begin{array}{c}\text { Number of } \\
\text { Deaths }\end{array}$ & $\begin{array}{c}\text { Behavioural } \\
\text { Changes }\end{array}$ \\
\hline 1 & A & 3 & 10 & $0 / 3$ & Normal \\
& B & 3 & 100 & $0 / 3$ & Normal \\
& C & 3 & 1,000 & $0 / 3$ & Normal \\
& D & 2 & 2,000 & $0 / 2$ & Normal \\
& E & 2 & 3,000 & $0 / 2$ & Normal \\
& F & 2 & 4,000 & $0 / 2$ & Normal \\
& G & 2 & 5,000 & $0 / 2$ & Normal \\
\hline
\end{tabular}

Table 3: The effect of the C. papaya-based ISCOM on neutrophil activation.

\begin{tabular}{|c|c|c|c|c|c|c|c|c|}
\hline \multirow[t]{2}{*}{ Treatment Groups } & \multirow[t]{2}{*}{$\begin{array}{l}\text { Dose }(\mathrm{mg} / \\
\mathrm{Kg})\end{array}$} & $\begin{array}{l}\text { Total Leucocyte } \\
\text { Count }(103 / \mathrm{mm} 3)\end{array}$ & $\begin{array}{l}\text { Total Leucocyte } \\
\text { Count }(103 / \mathrm{mm} 3)\end{array}$ & $\begin{array}{c}\text { Neutrophil } \\
\%\end{array}$ & $\begin{array}{c}\text { Neutrophil } \\
\%\end{array}$ & $\begin{array}{l}\text { Neutrophil } \\
\text { Index }\end{array}$ & $\begin{array}{l}\text { Neutrophil } \\
\text { Index }\end{array}$ & \multirow{2}{*}{$\begin{array}{l}\text { Neutrophil } \\
\text { Adhesion } \\
\text { (\%) }\end{array}$} \\
\hline & & Untreated Blood & $\begin{array}{l}\text { Fiber Treated } \\
\text { Blood }\end{array}$ & $\begin{array}{l}\text { Untreated } \\
\text { Blood }\end{array}$ & $\begin{array}{l}\text { Fiber Treated } \\
\text { Blood }\end{array}$ & $\begin{array}{l}\text { Untreated } \\
\text { Blood }\end{array}$ & $\begin{array}{l}\text { Fiber Treated } \\
\text { Blood }\end{array}$ & \\
\hline Distilled Water & 10 & $6.70 \pm 0.27$ & $6.57 \pm 0.15$ & $40.67 \pm 2.60$ & $37.67 \pm 3.76$ & $273.83 \pm 27.91$ & $248.43 \pm 30.02$ & $9.587 \pm 1.75$ \\
\hline $\begin{array}{l}\text { Levamisole (Positive } \\
\text { Control) }\end{array}$ & 100 & $8.70 \pm 0.25$ & $8.60 \pm 0.25$ & $51.67 \pm 1.45$ & $41.33 \pm 0.67$ & $450.03 \pm 24.11$ & $355.13 \pm 4.59$ & $20.74 \pm 3.31^{* *}$ \\
\hline $\begin{array}{l}\text { Organism(Negative } \\
\text { Control) }\end{array}$ & 0.1 & $4.27 \pm 0.33$ & $3.60 \pm 0.12$ & $32.67 \pm 1.76$ & $29.00 \pm 3.22$ & $138.73 \pm 8.57$ & $103.67 \pm 8.42$ & $24.47 \pm 8.59^{* *}$ \\
\hline $\begin{array}{l}\text { Organism then } \\
\text { ISCOM }\end{array}$ & $0.1+250$ & $6.00 \pm 0.23$ & $5.77 \pm 0.19$ & $38.33 \pm 1.45$ & $35.33 \pm 0.67$ & $230.67 \pm 17.60$ & $203.67 \pm 6.42$ & $11.09 \pm 4.10$ \\
\hline $\begin{array}{l}\text { ISCOM then } \\
\text { Organism }\end{array}$ & $250+0.1$ & $8.33 \pm 0.18$ & $7.93 \pm 0.20$ & $48.00 \pm 1.16$ & $42.33 \pm 1.45$ & $400.4 \pm 17.95$ & $336.23 \pm 18.66$ & $16.03 \pm 2.42^{*}$ \\
\hline
\end{tabular}

\section{Immunological evaluation}

Neutrophil adhesion test: Table 3 shows the effect of the C. papayabased ISCOM on neutrophil activation.Treatment with ISCOM resulted in an increase in neutrophil adhesion compared to water treated control animals. However, neutrophil adhesion decreased significantly when the animals were treated with organism. This decrease was significantly reversed when the organism-treated animals were supplemented with ISCOM derived fraction at $250 \mathrm{mg} / \mathrm{kg}$. Animals were prepared and described in the experimental section on immunological evaluation. The neutrophil index calculated from total leucocyte and neutrophils counts was used to determine the percent neutrophil adhesion. The neutrophil index was calculated for the treatment groups and analysed for statistical difference in GraphPad PRISM. Data are presented as means \pm SEM obtained from 3 experiments $\left({ }^{*} p<0.05\right.$; or $\left.^{\star *} p<0.001\right)$ compared to distilled water.

Carbon clearance assay: To demonstrate the phagocytic activity using ISCOM, groups treated with formulated ISCOM showed concentration dependent phagocytic activity when compared with control groups. The phagocytic indices of $250 \mathrm{mg} / \mathrm{kg}$ of ISCOM showed significant $(p<0.01$; $p<0.001)$ increase as presented in Figure 1. The result showed that ISCOM exhibited more potent phagocytic activity when compared to the control group.

Hemagglutination antibody titre: To demonstrate antibody titre activity of ISCOM, administration of ISCOM produced significant $(p<0.01)$ humoral antibody titre as compared to control (Figure 2). Animals were treated as indicated in Figure 2. Data are presented as means \pm SEM from 4 experiments $\left({ }^{* *} p<0.001\right.$ while $\left.{ }^{* * *} p<0.0001\right)$ compared to organism only. The lower titre value indicates the potency of the formulated ISCOM to elicit an immune response. The ISCOM dose ( $250 \mathrm{mg} / \mathrm{kg}$ body weight) significantly elevated hem agglutination antibody titre (7.81 \pm 1.60$)$.

\section{DISCUSSION}

In medical science, immune stimulation is an area wherein extensive studies have been conducted to devise methods to improve disease resistance as well as prevent or control immune disorders of host by optimum regulation of the immune system. Today, most infectious diseases of man are treated and controlled mainly by using broadspectrum antibiotics and vaccines. However, the antibacterial agents are becoming increasingly ineffective due to rapid emergence of resistant microbial strains. So, there is urgent need for novel and improved alternative therapeutic and prophylactic strategies to manage several immune-related diseases. Immunostimulation is focused on manipulation of immune system to control the infections and other adverse health effects with precise regulation to avoid any complications while suppressive or potentiating efforts are made to benefit the human health. The main aim of this study was to explore the potential immunostimulatory effect of C. papaya-based ISCOM.

The use of ethnomedicinal plants as immunostimulatory agents has been more pronounced recently as plant extracts have widely been explored during last few decades in various parts of the world for their possible immunostimulatory properties. Many studies have demonstrated the isolation of potential bioactive molecules which have been patented and have been tested as herbal formulations. ${ }^{29,30}$ This study shows the percentage yield of aqueous extraction of saponinfrom C. papaya leaves as $7.45 \%$. The saponin content of C. papaya leaves have been established by several other studies as responsible for the bitter taste of the leaves. ${ }^{1,2,4}$ ISCOM was formulated using ethanol injection method due to its low 
cost, simplicity, short time of preparation and high yield of homogenous ISCOM. ${ }^{21}$

In the acute toxicity study and at $5000 \mathrm{mg} / \mathrm{kg}$ body weight, no death was recorded and behavioural characteristics were normal. This supports the findings of Sahgal et al. ${ }^{24}$

The formulated C. papaya-based ISCOM had significant increase in phagocytic function of immune cells specifically neutrophils as compared to control suggesting immune enhancing effect. Pathogens are identified and destroyed by immune cells by the action of phagocytosis. ${ }^{31}$ Neutrophil adhesion to nylon fibre models the movement of polymorph nuclear lymphocytes through blood vessel walls and macrophages towards inflammation site, by the action of neutrophils in the neutrophil adhesion test. ${ }^{32,33}$ This implies stimulatory effect of neutrophil migration to inflammatory site. Formulated C. papaya-based ISCOM showed significant difference in the neutrophil adhesion (20.82 \pm 4.34$)$ at a dose of $250 \mathrm{mg} / \mathrm{kg}$ for test group when compared to the negative control group (9.587 \pm 1.75$)$. The adhesion of neutrophils to nylon fibre might be connected with up-regulation of $\beta_{2}$ integrins as reported by Srikumar et al. ${ }^{28}$

Carbon clearance assay is used to evaluate effect on reticuloendothelial cell mediated phagocytosis. ${ }^{34}$ Macrophages engulf carbon particles in ink containing colloidal carbon, when the ink containing colloidal carbon is injected intravenously. The ISCOM when solely administered stimulated the reticuloendothelial system causing significant increase in the phagocytic index. ISCOM possesses macrophage stimulatory activity as evidenced by increased phagocytic index in carbon clearance test indicating stimulation of the reticuloendothelial system. The neutrophils are constituents of the white blood cell that normally identify, engulf and digest a bacterium according to earlier report. ${ }^{30}$

Antibody functions as effectors of humeral response by binding to antigen and neutralizing or enhancing its elimination via cross-linking to form clusters that are ingested by phagocytic cells. B cells interaction with antigen and proliferation and differentiation to antibody secreting plasma cells is characterize in humoral immunity. ${ }^{35,36}$ There will be agglutination if the serum contains antibody to the organism. The increase antibody percentage stimulation value by the ISCOM only indicates the responsive effect of macrophages, $\mathrm{T}$ and $\mathrm{B}$ lymphocyte subset involved in the synthesis of antibodies when compared to the standard.

\section{CONCLUSION}

C. papaya leaves yielded saponin which served as a component of ISCOM formulation to induce both cell and antibody mediated immune responses. C. papaya-based ISCOM may be useful as an immune enhance against Streptococcus pneumoniae infections. It can also be inferred that C. papaya-based ISCOM has therapeutic and immunomodulatory activities.

\section{ACKNOWLEDGEMENT}

Authors wish to thank Chibueze Jeremiah Ike for his technical support throughout the course of the experiments.

\section{CONFLICT OF INTEREST}

The authors declare no conflict of interest.

\section{ABBREVIATIONS}

ISCOMs: Immunostimulatory complexes; DLC: differential leucocyte count; EDTA: Ethylenediaminetetraacetic acid; WBC: White Blood
Cell; TLC: Total Leucocyte Count; NI: neutrophil index; HA: Hemagglutinating antibody; ANOVA: Analysis of Variance.

\section{REFERENCES}

1. Santana LF, Inada AC, Espirito SBLSD, Filiú WFO, Pott $A$, Alves FM, et al. Nutraceutical Potential of Carica papaya in Metabolic Syndrome. Nutrients. 2019;11(7):1608.

2. Shubham S, Mishra R, Gautam N, Nepal M, Kashyap N, Dutta K. Phytochemical Analysis of Papaya Leaf Extract: Screening Test. EC Dental Science. 2019;18(3):485-90.

3. Okigbo RN, Anuagasi CL, Amadi JE. Advances in selected medicinal and aromatic plants indigenous to Africa. J Med Plants Res. 2009;3(2):86-95.

4. Srivastava AK, Singh VK. Carica Papaya: A Herbal Medicine. Int J Res Studies Biosci. 2016;4(11):19-25.

5. Weiser JN, Ferreira DM, Paton JC. Streptococcus pneumoniae: Transmission, colonization and invasion. Nat Rev Microbiol. 2018;16(6):355-67.

6. Rudan I, Boschi-Pinto C, Biloglav Z, Mulholland K, Campbell H. Epidemiology and etiology of childhood pneumonia. Bull World Health Organ. 2008:86(5):40816.

7. Mollendorf VC, Tempia S, Gottberg AV Meiring S, Quan V Feldman C et al. Estimated severe pneumococcal disease cases and deaths before and after pneumococcal conjugate vaccine introduction in children younger than 5 years of age in South Africa. PLoS One. 2017;12(7):e0179905.

8. Brooks LRK, Mias GI. Streptococcus pneumoniae's Virulence and Host Immunity: Aging, Diagnostics and Prevention. Front Immunol. 2018;9:1366.

9. Berical AC, Harris D, Dela CCS, Possick JD. Pneumococcal Vaccination Strategies. An Update and Perspective. Ann Am Thorac Soc. 2016;13(6):933-44.

10. Chowdhury RR, Ghosh SK. Phytol-derived novel isoprenoid immunostimulants. Front Immunol. 2012;3:49.

11. Puggioni F, Alves-Correia M, Mohamed MF, Stomeo N, Mager R, Marinoni M, et al. Immunostimulants in respiratory diseases: Focus on Pidotimod. Multidiscip Respir Med. 2019;14(1):31.

12. Hem SL, Johnson CT. Production and characterization of Aluminum-containing adjuvants. Vaccine Dev Manuf. 2014;(11):319-46.

13. Odimegwu DC, Onah Al, Ifudu F, Oli AN. Evaluation of levamisole as an adjuvant for typhoid fever vaccine formulation. PhOL. 2019;2:336-46.

14. Ngcobo M, Gqaleni N. Evaluation of the immunomodulatory effects of a South African commercial traditional immune booster in human peripheral blood mononuclear cells. BMC Complement Altern Med. 2016;16(1):300.

15. Oli AN, Obialor WO, Ifeanyichukwu MO, Odimegwu DC, Okoyeh JN, Emechebe $\mathrm{GO}$, et al. Immunoinformatics and Vaccine Development: An Overview. Immunotargets Ther. 2020;9:13-30.

16. Sjölander A, Cox JC, Barr IG. ISCOMs: An adjuvant with multiple functions. J Leukoc Biol. 1998;64(6):713-23.

17. Lövgren BK, Morein B, Osterhaus AD. ISCOM technology-based Matrix $M^{\mathrm{TM}}$ adjuvant: Success in future vaccines relies on formulation. Expert Rev Vaccines. 2011:10(4):401-3.

18. National Research Council (US) Committee for the Update of the Guide for the Care and Use of Laboratory Animals. Guide for the Care and Use of Laboratory Animals. $8^{\text {th }}$ edition. Washington (DC): National Academies Press. 2011. ISBN13: 978-0-309-15400-0.

19. Veterinary Surgeon Act Cap V3 LFN, Federal Republic of Nigeria. "The Care and Use of Animals for Scientific Purposes. 2004.

20. Animal Diseases (Control) Act. Cap A17 LFN, Federal Republic of Nigeria "The Care and Use of Animals for Scientific Purposes. 2004.

21. Ojiako CM, Okoye El, Oli AN, Ike CJ, Esimone CO, Attama AA. Preliminary studies on the formulation of immune stimulating complexes using saponin from Carica papaya leaves. Heliyon. 2019;5(6):e01962.

22. Lendemans DG, Myschik J, Hook S, Rades T, Immunostimulating complexes prepared by ethanol injection. J Pharm Sci. 2005;57(6):729-33.

23. Lorke D. A new approach to practical acute toxicity testing. Arch Toxicol. 1983;54(4):275-87.

24. Sahgal G, Ramanathan S, Sasidharam S, Mordi MN, Sabariah IS, Manor SM. Brine shrimp lethality and acute oral toxicity studies on Swietenia mahagony (Linn.) Jacq: Seed methanolic extract. Pharmacog Res. 2010;2(4):215-20.

25. Mallurwar VR, Joharapurkar AJ, Duragkar NJ. Studies on immunomodulatory activity of Mucunapruriens. Indian J Pharma Edu Re. 2006;40(3)205-7.

26. Cheng W, Li J, You T, Hu C. Anti-inflammatory and Immunomodulatory activities of the extracts from the inflorescence of Chrysanthemum indicium Linn. J Ethnopharmacol. 2005;101(1-3):334-7.

27. Puri A, Saxena R, Saxena RP, Saxena KC. Immunomodulant agents from Andrographis paniculata. J Nat Prod. 1993;56(56):995-9.

28. Srikumar R, Narayanaperumal JP, Rathisamy SD. Immunomodulatory activity of Triphala over neutrophils functions. Bio Pharm Bull. 2005;28(Suppl 8):1399-403.

29. Okwu DE, Okwu ME. Chemical composition of Spondiacmombin plants. J Sustain Agric Environ. 2004;6:140-7. 
30. Carrió E, Rigat M, Garnatje T, Mayans M, Parada M, Vallès J. Plant ethnoveterinary practices in two pyrenean territories of catalonia (iberian peninsula) and in two areas of the balearic islands and comparison with ethnobotanical uses in human medicine. Evid Based Complement Alternat Med. 2012;2012:896295.

31. Segal AW. The function of NADPH oxidase of phagocytes and its relationship to other NOXs in plants, invertebrate and mammals. Int J Biochem and Cell Biol. 2008;40(4-3):604-18.

32. Malech HI, GallinJL. Current concepts: Immunology. Neutrophils in human diseases. N Engl J Med, 1987;1:317.

33. Oli AN, Emeruwa AP, Ekwunife OI, Okoye EL, Anyaoku CS, Ibeanu GC, et al.
Pleurotus ostreatus Extract Enhances the Phagocytic Actions of Neutrophils against Streptococcus pneumoniae. Ann Med Health Sci Res. 2019;9:499-508.

34. Jayathirtha MG, Mishra SH. Preliminary immunomodulatory activities of methanol extracts of Ecliptaalba and Centelleasiatica. Phytomedicine. 2004;11(4):361 5

35. Cano RLE, Lopera HDE. Introduction to T and B lymphocytes. Autoimmunity: From Bench to Bedside. Bogota: El Rosario University Press. 2013. Chapter 5.

36. Hoffman W, Lakkis FG, Chalasani G. B Cells, Antibodies and More. Clin J Am Soc Nephrol. 2016:11(1):137-54

Article History: Submission Date : 12-04-2020; Revised Date : 22-05-2020; Acceptance Date : 26-07-2020.

Cite this article: Briggs TA, Oli AN, Okoye El, Obajuluwa AF, Ezejiegu C, Ofomata CM, et al. Assessment of immunostimulating effect of Carica papaya-based Immunostimulatory complexes against Streptococcus pneumoniae infections. Int. J. Pharm. Investigation, 2020;10(3):384-9 